\title{
DETERMINANTS OF BANKING INDUSTRY PROFITABILITY: AN EMPIRICAL RESEARCH OF INDONESIA FINANCIAL INSTITUTIONS
}

\author{
Suwinto Johan \\ suwintojohan@gmail.com \\ Faculty of Business, President University
}

\begin{abstract}
ABSTRAK
Penelitian ini bertujuan untuk mempelajari determinan profitabilitas perbankan di Indonesia. Penelitian difokuskan pada 19 bank yang dikategorikan sebagai bank book 3 dan 4 sesuai ketentuan bank sentral. Tujuh rasio keuangan utama, yaitu dampak pemegang saham (bank swasta versus bank milik negara), dan status dampak bank (bank milik lokal versus bank milik asing) dianalisis sebagai penentu profitabilitas bank. Kami menggunakan data panel seimbang dan menguji statistik model dengan pooled least square, model efek tetap, atau model efek acak dengan menggunakan program Eviews. Sampelnya adalah 19 bank yang mempublikasikan laporan tahunannya dari tahun 2016-2018. Hasil empiris menunjukkan bahwa determinan utama profitabilitas perbankan adalah kredit macet. Pinjaman bermasalah yang lebih tinggi akan membutuhkan persyaratan cadangan yang lebih tinggi. Persyaratan cadangan yang lebih tinggi akan berdampak pada profitabilitas bank. Selain itu, penentu utama pengembalian ekuitas adalah status kepemilikan bank (kepemilikan lokal versus kepemilikan asing). Pemegang saham lokal menunjukkan lebih banyak dukungan untuk profitabilitas perbankan daripada pemegang saham asing. Variabel signifikan kurang dari 1\%, dan hanya status pengaruh bank terhadap return on equity yang signifikan pada kurang dari $10 \%$.
\end{abstract}

Kata kunci: lembaga keuangan, rasio keuangan, rasio profitabilitas

\begin{abstract}
The research aims to analysis the determinants of financial industry profitability, especially banking in Indonesia. The research concentrated on the 19 banks that are classified as bank group 3 and 4 as per the Indonesia central bank guideline. The seven main business ratios, which are shareholders' influence (private-owned versus stateowned), and position of the shareholders banks' (local ownership versus foreign-ownership or joint venture) impact were evaluated as bases of banks' profitability. We use balanced panel data and test the model statistical by pooled least square, fixed-effect model, or random-effect model by utilize E-views software. The samples are 19 banks who published their annual report in their company website since 2016 to 2018. The empirical results confirm that the principal factor influence banking profitability is non-performing loans or bad debt. Higher bad debt will require higher reserve requirements. Higher reserve requirements will influence on the profitability of the bank. Moreover, the principal factor influence return on equity is the ownership status of the bank (local ownership versus foreign ownership). Local shareholders presented more support for banking profitability than foreign shareholders. The variable is significant at less than $1 \%$, and only the bank's ownership status influence on return on equity has significant at less than $10 \%$.
\end{abstract}

Key words: financial institutions, financial ratio, profitability

\section{INTRODUCTION}

The banking structure performs the function of new capital creation in the economy of a country. Banking is a significant contributor to economic development of a country. If economy of country is going well, then the bank's profitability will also be useful. Conversely, if a country's economy is in recession, banks will also experi-ence problems. 


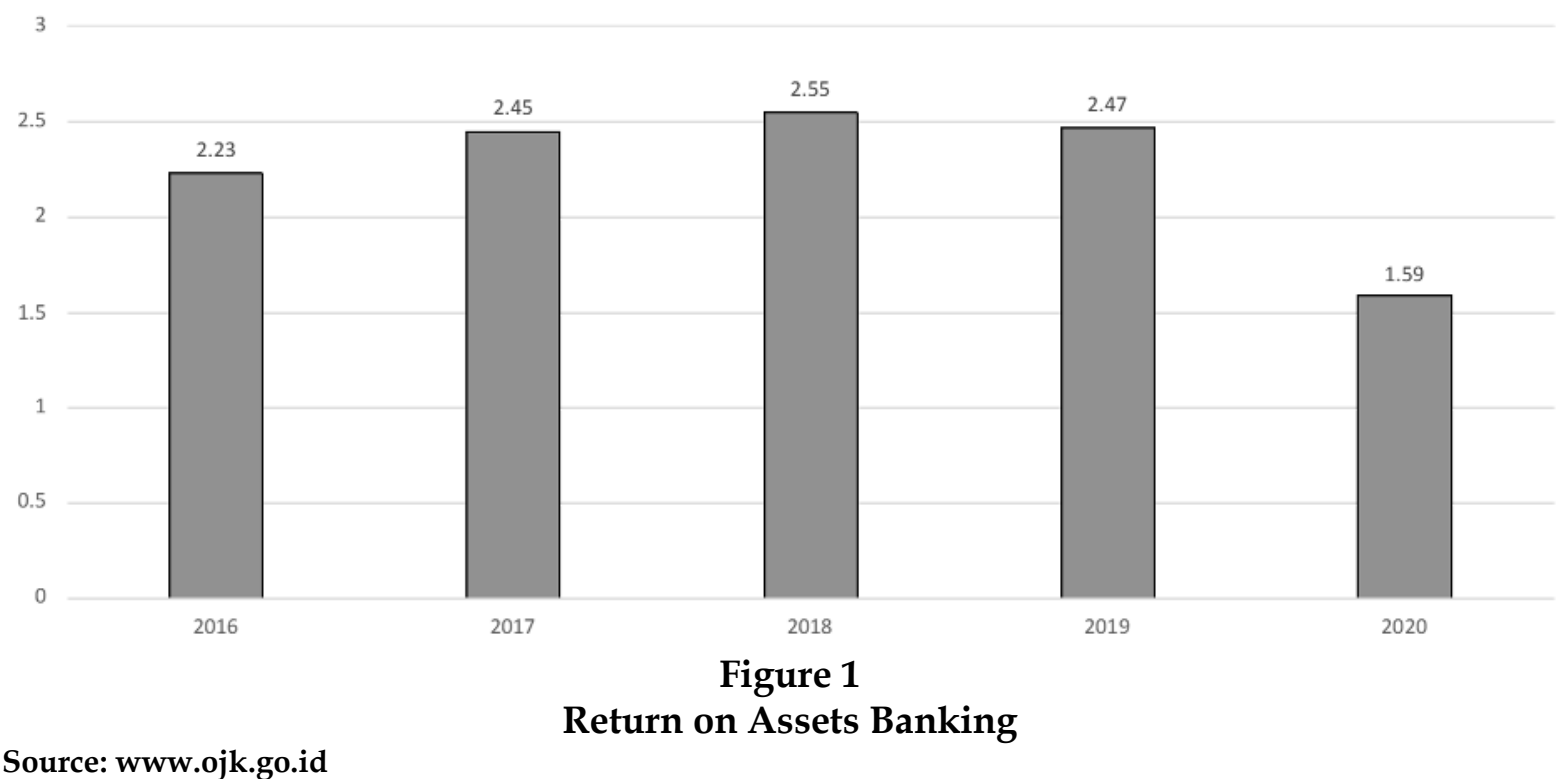

Source: www.ojk.go.id

In 1998, when Asia experienced an economic crisis, several countries experienced a banking crisis as well. Indonesia is one of the countries that experienced the 1998 banking crisis. The number of banks liqui-dated totaled 16 banks, and banks under the supervision of the Indonesia Banking Restructuring Agency (IBRA) amounted to 54 banks

According to figure 1, in 2020, banking industry experienced a decline on return on assets from $2.47 \%$ in 2019 to $1.59 \%$ in 2020 (OJK, 2021). The results as explained in Figure 1. The Covid-19 pandemic resulted in a decline in banking profitability. The government took several policies to overcome the pandemic and economics challenges, such as large-scale social restrictions (PSBB) to debt restructuring for customer who impacted by the COVID-19. Banking profitability have declined in line with the government's macroeconomic policies. Banking profits can be influenced by macro variables and micro variables. Macro variables are external variables for banks such as government policies regarding interest rates, inflation and other monetary policies. Micro variables are variables that exist wi-thin the bank itself. Micro variables are variables related to bank management, such as capital structure policies, credit policies, credit growth policies and others.

Since then, the banking industry has been strictly supervised by the Financial Service Authority (Otoritas Jasa Keuangan /OJK), with the Bank Indonesia (Central Bank of Republic Indonesia) keeping a tight eye on it. There are further restrictions on ownership, the quantity of loans to linked parties, and exposure to specified industries. There is also meticulous reporting. Individual ownership is restricted to a maximum of $40 \%$.

Banking investors demand bank profits to be matched with the risks when there is a high level of risk. During the years 20162018, banks' average return on equity in Book 3 and 4 was 11.95 percent each year. As a result, Tan (2016) reported no signify-cant findings on the effects of market structure and risk on bank profitability, whereas tax rate, overhead cost, labor pro-ductivity ratio, and consumer price index all had an impact on Chinese banking profi-tability.

The current study is unusual in that it looked at the determinants of banking profitability using two proxies, Return On Equity (ROE) and Return On Assets (ROA), and concentrated on banks classified as Books 3 and 4 under Indonesian rules. According to Bank Indonesia regulation No. 14/26/PBI/ 
2012, banks are divided into four categories: (1) Bank Books I, with total equity of less than Rp1 trillion; (2) Bank Books II, with total equity of IDR 1 trillion to IDR 5 trillion; (3) Bank Books III, with total equity of IDR 5 trillion to IDR 30 trillion; and (4) Bank Books IV, with total equity of more than IDR 30 trillion.

\section{LITERATUR REVIEW}

\section{Determinants Banks' Profit in Developing Market}

Lipunga (2014) evaluated the determinants of publicly listed commercial banks' profitability in emerging markets. The results of the statistic analysis suggested that bank size, liquidity, and management efficiency have statistically robust impacts on ROA; however, capital adequacy has an insignificant effect. Meanwhile, results suggested that earnings yield is significantly influenced by total bank assets, capital adequacy ratio, and management efficiency, whereas liquidity was found to have an insignificant impact on interest yields.

According to Maryadi and Basuki (2014), who analyzed the impact of banking management (liquidity, credit distribution, assets quality, operational efficiency rate) to ROA of rural banks in Indonesia, the results showed that CAR (Capital Adequacy Ratio) has positive and significant effects on ROA.

Tariq (2014) examined the influence of determinants on commercial banks' results in Pakistan. They found that the total equity strength of a bank has the utmost significance in affecting its performance, as well as a well-capitalized bank. The assets quality also affects the bank's performance positively.

Béjaoui and Bouzgarrou (2014) researched that the character of bank-spe-cific and the continuity of determinatns on bank profitability in Tunisia. The results found a positive influence between capital and profitability. Next, Capraru and Ihnatov (2015) found that expense to revenue ratio, credit risk, and market landscape had a negative impact on the bank's profitability, and liquidity only for interest yield and Return On Average Equity (ROAE).

Petria et al., (2015) stated that bad debt risk and liquidity risk, the cost to revenue ratio, business diversification, concentration of the market, and growth of economic have influences on bank profitability, both on ROA and ROE. Leverage and liquidity indicate insignificant impacts on profitability. Mwangi and Murigu (2015) found that profitability is positively related to capital size, debt to equity ratio, and management key competence index, and is negatively related to firm size and ownership structure.

Samad (2015) examined the impact of bank-specific characteristic and macro variables in determining the banks' profitability of the Bangladesh banking industry. The results indicated that loan deposits, loan loss provision, leverage ratio, and efficiency ratio are significant factors.

Meanwhile, Marnilin and Darmansyah (2015) researched on determinants analysis of earning persistence in the service companies on the Indonesia stock exchange. The results showed that the rate of debt is signifycantly affecting earnings persistence. The concentrated ownership structure increases the relationship between IFRS adoption and earning quality (Utami and Kusuma, 2017).

Ahmad (2015) analyzed determinants that affect the State Development Bank's (BPD) profitability. The research found that bank efficiency, Non-Performing Loans (NPL), and NIM have significant impacts on profitability of banks.

Next, Islam and Nishiyama (2016a) discovered that the yield on funds, liquidity ratio, funding-lending gap ratio, term structure of interest rate, and economic growth rate all have a negative impact on bank financial performance, however the consumer price index rate has a favorable impact.

Haryanto (2016) investigated the effects of lending, bank equity, leverage structure, business efficiency, and risk on banking profitability. The findings revealed that a bank's profitability is influenced by lending, 
bank equity, and leverage structure. Other studies revealed that corporate efficiency and risk had a considerable negative impact on profit.

Abdillah et al., (2016) investigated the determinants of profitability performance and liquidity ratio in three Indonesian Syariah banks. The quick ratio and expense to income ratio have negative and substantial effects on profitability, whereas the Capital Adequacy Ratio (CAR) has a positive and substantial impact on the firm's net income, according to the report.

Chou and Buchdadi (2016) found that the cost-to-income ratio and nonperforming loans (NPLs) were important factors in characterizing rural bank outcomes in Indonesia. The findings revealed that the banking business in Indonesia need efficiency and risk management. Furthermore, according to Zainuddin et al., (2017), the cash ratio and loan deposit ratio have no favorable influence on ROA. Ten banks were studied between 2011 and 2015.

According to Tui et al., (2017), intellecttual capital has a positive and significant impact on firm profitability and value; total assets has a positive but insignificant impact on firm profitability and value; liquidity has a positive and significant impact on firm profitability but an insignificant negative impact on firm value; and firm profitability has a positive and significant impact on firm profitability and value.

The research of Ozili and Uadiale (2017) focuses on bank ownership concentration, which is defined as the number of direct shares owned by a single majority shareholder and is classified as high, moderate, or dispersed ownership. They discovered that banks with concentrated ownership had better ROA, NIM, and recurring earning potential than banks with dispersed ownership, which had lower ROA but greater ROE.

The micro factors such as capital adequacy ratio, management efficiency measurement, earnings, and liquidity ratios significantly affected equity return, whereas the Net Interest Margin (NIM) was significantly affected only by capital adequacy ratio and earnings ratios. The industry-particular factor proxied by the industry growth rate was having a significant effect on NIM (Rani and Zergaw, 2017).

Asset management, firm size, and capital ratio are positively connected with bank profitability. At the same time, non-performing loans and operating efficiency affect the bank's profits negatively. Additionally, macroeconomic factors have a different impact on profitability indicators in each market. The research contributes to decisionmakers inside and outside the bank to regulate important factors affecting bank profitability (Sahyouni and Wang, 2018).

Banks can improve their profitability through mounting capital and liquidity, diminishing operating costs with a conscious effort to maintain transparency in their operations. Besides, an excellent economic atmosphere for financial organizations fosters a rise in bank profitability (Ebenezer et al., 2017).

Equity to total assets, non-performing loans to total cash loans, net interest revenues to average total assets, and central bank policy interest rate significantly influence return on assets. In contrast, non-interest income to total assets, market share of deposit banks in the banking sector, operational expenses to average total assets, and exchange rate are not statistically significant (Ozgur and Gorus, 2016).

Credit risk or non-performing loan ratio, NIM, capital adequacy ratio, and consumer price index were the most critical variables that significantly affect banks' profitability in both Ghana and India. The cost to income ratio and bank size had an insignificant impact on the profitability of Indian banks but significantly impacted Ghanaian banks' profitability (Boateng, 2018).

The Zimbabwean banking industry's profitability can be improved by increasing the credit quality of the assets, improving efficiency management, and improving liquidity ratio and capital levels. The study confirms that bank managers have a signi- 
ficant role in shaping the profitability of the industry (Abel and Roux, 2016).

Diversified banking businesses, including investment activities, made these banks more profitable. Diversified banking businesses are welcomed, but if these activities include a higher part of volatile trading activity than low-risk income streams like fees and commission, the risk may become higher (Islam et al., 2017).

Higher GDP comes with higher bank profitability for post-Soviet countries. Lastly, there is a negative relationship between the loan-to-GDP ratio and the banks' profitability in post-Soviet countries. This means that when the ratio of total loans to GDP increases, it affects the financial performance of the banks in a negative way (Yüksel, 2018).

Capital Adequacy Ratio, Income Diversification, and Inflation Ratio are positive and significantly associated with the dependent variable return on the asset; on the other hand, non-performing loan to total loan, liquidity ratio, bank size, and non-traditional activities are negative and significantly associated with the dependent variable return on asset (Majumder and Uddin, 2017).

Credit quality, operational efficiency, banking sector development, inflation, and industry concentration are found to be negatively and significantly related to banks' profitability. Further, this study found lower profitability of banks during the government transition. The Mean comparison of profitability indicates that Specialized Banks (SB) in Pakistan are generating a higher Net Interest Margin (NIM) than All Commercial Banks (ACB). However, the empirical results of this study are robust and consistent with previous literature (Yao et al., 2018).

Bank profitability demonstrated moderate persistence and ignoring the countryspecific features could lead to bias and poor estimations. The conclusions of this research would aid in setting banking policies towards increasing profitability. This may be supplemented by ensuring strong research departments within the banks tasked with analyzing and forecasting the leading macro- economic indicators (Hasanov et al., 2018). This research focuses on macro indicators, however macro indicators are not indicators that can be controlled by company management. Company management can only take action within the company to anticipate macro policies.

Liquidity ratio, business mix indicators, interest rates, and industrial production deteriorates bank profitability. Liquidity risks enhance the probability of default risks and transmit into the unpaid loans and lower returns (Rahman et al., 2020). This study shows unusual results, namely that interest rates and business mix reduce bank profitability. This research needs to explain the research time.

A significant relationship between bankspecific determinants (size, cost management, and liquidity) and bank profitability (ROA) before, during, and after the financial crisis. However, the relationships between other bank-specific (capital strength, credit risk, and market power), macroeconomic (GDP and inflation) determinants are sensitive to both periods of analysis (before, during, and after the financial crisis) and bank profitability measure used (ROA or NIM). Overall, these results suggest that the financial crisis did not affect the relationships between bank-specific determinants and bank profitability (Adelopo et al., 2018). This research is unique in finding that banking performance and the determinants variable do not have differences in pre-crisis, crisis and post-crisis.

A measurement of banks' profitability is the Return On Assets (ROA) and the Return On Equity (ROE). The results indicate that capital adequacy, capital, and leverage positively affect the banks' profitability, and the variable of assets quality negatively affects the banks' profitability (Alshatti, 2016).

The empirical analysis revealed that both macroeconomic forces and industryrelated factors affect bank profitability. As far as the macroeconomic factors are concerned, the unemployment rate has a negative impact, whereas the GDP growth rate posi- 
tively impacts bank profitability. The industry-related factors, rate of growth of the industry's deposits, and bank's assets market share have a positive impact on the bank's financial performance. Finally, the growth rate of the industry's assets and the bank's deposit market share harm bank profitability (Zampara et al., 2017).

Hasanov et al., (2018) stated that Net Interest Margin (NIM), Ratio of Operational Expenses to Operational Profit, Capital Adequacy Ratio (CAR), and Loan to Deposits Ratio (LDR) significantly affected profitability bank of return of equity. Islam and Nishiyama (2016b) found no relationship evidence for the traditional Structure Conduct and Performance (SCP) hypothesis to banking profit, but financial solvency and managerial merit have a positive relationship. The cost of the fund, liquidity, funding structure, term structure of interest rate, and economic development rate found a negative effect while the consumer price index rate positively influences bank profit.

Banks' profitability and its determinants in Tunisia as well as in 13 different countries were investigated. The determinants of bank profitability are analyzed with the data from 110 banks over the period 1999-2012 using the panel data method generalized method of moments. Our results suggest that researchhers should probably focus more on profit efficiency than cost efficiency. Almost all banks are below the optimal size (Rekik and Kalai, 2017).

Saona (2016) found that evidence of several vital relationships involving bank profitability, including 1) an inverse U-shaped association between banks' capital ratios and profitability, 2) a positive association between asset divergence (e.g., security trading, hedge funds, foreign exchange, assurance, etc.) and profitability, 3) a negative association between revenue diversification (e.g., interests, fees, commissions, etc.) and profitability, 4) a positive association between market strength and profitability, and 5) improvements in the legal and regulatory system are related with a negative effect on banks' profitability.

\section{Determinant Banks' Profit in Developed Market}

During the period 2004-2011, Capraru and Ihnatov (2014) examined the key factors of bank profitability in five Central Eastern European (CEE) nations. The findings of the study revealed that bank profitability is influenced by efficiency and capital adequacy growth. Dietrich and Wanzenried (2014) also looked at how bank-specific metrics, macroeconomic variables, and industry-specific factors affect banking profitability. The level of income had a significant impact on the factors that determined bank profitability.

The cost measures the efficiency of the banking industry to income ratio and the non-performing loans ratio, which signifycantly impacts bank profitability, both on ROA and ROE. In the post-crisis phase, banking firms ask for efficient cost organization in achieving performance purposes. Other significant research results are the nonexistence of assets size and regulatory capital ratio on profitability measurements. The principal contribution is related to the sample definition, variable collection, and explanatory power of the presented model in explaining worldwide banking tendencies (Ercegovac et al., 2020).

Bank industry characteristics and macroeconomic variables affect bank profitability. The direction of causality is not uniform across profitability measures. (Batten and Vo, 2017). Bank's firm size and non-interest income had a significant positive relationship on banking profitability deposit. It had a significant negative correlation with banking profitability because of maintaining high liquidity, which increased the cost of holding an asset that ultimately decreased profitability (Javid, 2016). 
Table 1

Summary of previous research

\begin{tabular}{|c|c|c|c|}
\hline Variable & Significant & Significant Positive & Significant Negative \\
\hline $\begin{array}{l}\text { Capital } \\
\text { Structure }\end{array}$ & $\begin{array}{l}\text { Lipunga (2014), } \\
\text { Tariq (2014), Samad } \\
\text { (2015), Ahmad } \\
\text { (2015), Petria et al., } \\
\text { (2015) }\end{array}$ & $\begin{array}{l}\text { Béjaoui and Bouzgarrou } \\
\text { (2014), Maryadi and Basuki } \\
\text { (2014), Mwangi and Murigu } \\
\text { (2015), Capraru and Ihnatov } \\
\text { (2015), Haryanto (2016), } \\
\text { Zainuddin et al., (2017), } \\
\text { Alshatti (2016) }\end{array}$ & $\begin{array}{l}\text { Zaid et al., (2014), Tui } \\
\text { et al., (2017) }\end{array}$ \\
\hline Credit Risk & $\begin{array}{l}\text { Tariq (2014), Petria } \\
\text { et al., (2015), Chou } \\
\text { and Buchdadi } \\
\text { (2016), Ercegovac et } \\
\text { al., (2020) }\end{array}$ & $\begin{array}{l}\text { Abdillah et al., (2016), } \\
\text { Haryanto (2016) }\end{array}$ & $\begin{array}{l}\text { Capraru and Ihnatov } \\
\text { (2015), Yao et al., } \\
\text { (2018) }\end{array}$ \\
\hline Profit Ratio & $\begin{array}{l}\text { Dietrich and } \\
\text { Wanzenried (2014) }\end{array}$ & Ahmad (2015) & \\
\hline Firm Size & $\begin{array}{l}\text { Lipunga (2014), Zaid } \\
\text { et al., (2014) }\end{array}$ & Tui et al., (2017), Javid (2016) & $\begin{array}{l}\text { Petria et al., (2015), } \\
\text { Mwangi and Murigu } \\
\text { (2015) }\end{array}$ \\
\hline $\begin{array}{l}\text { Ownership } \\
\text { Status }\end{array}$ & $\begin{array}{l}\text { Ozili and Uadiale } \\
\text { (2017) }\end{array}$ & Mwangi and Murigu (2015) & \\
\hline
\end{tabular}

Source: Research Result

\section{Non-Financial Industry}

In Malaysia, Zaid et al. (2014) investigate the factors that influence the profitability of public-sector construction firms. The findings of the study revealed that profitability is influenced by liquidity and size. The association between capital structures and profitability was found to be negligible and negative.

The financial industry has unique characteristics. The non-financial industry has efficient characteristics in terms of small size, but finance industry is attached to size for great performance. Banking assets are a source of income. Banks provide loans that have tenor from short term to long term. So that the results of research in the financial industry are different from the non-financial industry.

The liquidity ratio is an important ratio in the non-financial industry. The liquidity ratio is also an important ratio for the financial industry. However, for banks that have high liquidity ratios, their profitability will be low, because loan funds are a source of income. The more idle funds, the more a bank will face a negative spread.

Although, as indicated in Table 1, there are already numerous research concentrating on the drivers of banking profitability. The banking industry has yet to yield solid outcomes. As a result, it is critical to do study on this issue in developing nations like Indonesia.

In this study, the determinants of banking profitability in Indonesia from 2016 to 2018 will be examined. Financial performance and ownership status will be used to create performance factors.

The following were the primary research questions in this study: Is there a link between capital structure and bank profitability? Is there a link between credit risk and bank profitability? Is there a link between profit ratio and bank profitability? Does the size of a company affect the profitability of a bank? Is there a link between bank ownership and profitability? The 
research's major goal is to look at the factors that influence banking profi-tability in emerging markets, particularly Indonesia. One of the most important generators of economic growth is the banking industry. Banking profitability is also a significant source to national income. It is critical to investigate the factors that influence banking profitability. The outcomes will be used by management, shareholders, and regulators to make decisions about the industry.

\section{RESEARCH METHODS}

The 5 primary ratios on capital structure, credit risk, profit ratio, business size, and ownership status are the variables in this study. The influence of ownership on bank performance was measured specifically in this study. The impact of ownership status on profitability is measured by comparing the impact of foreign vs. domestic and private vs. government ownership. The following is the relevant panel data:

$$
\begin{aligned}
& Y_{1 i t}=a+b_{1} \text { Levr }_{i t}+b_{2} \text { CRs }_{i t}+b_{3} \text { Prv }_{i t}+ \\
& b_{4} F i S i_{i t}+b_{5} \text { OS }_{1 i t}+b_{6} \text { OS }_{2 i t}+ \\
& \varepsilon \ldots \ldots \ldots \ldots \ldots \ldots(1) \\
& Y_{2 i t}=a+b_{1} \text { Levr }_{i t}+b_{2} \text { CRs }_{i t}+b_{3} \text { Prv }_{i t}+ \\
& b_{4} F i S i_{i t}+b_{5} \text { OS }_{1 i t}+b_{6} \text { OS }_{2 i t}+ \\
& \varepsilon \ldots \ldots \ldots \ldots \ldots . .(2)
\end{aligned}
$$

Description:

$$
\begin{aligned}
\mathrm{Y}_{1 i \mathrm{i}}= & \text { ROA } \\
\mathrm{Y}_{2 \mathrm{it}}= & \text { ROE } \\
\text { Levr }= & \text { Capital Structure Ratio } \\
\mathrm{CRis}= & \text { Credit Risk } \\
\mathrm{Prv}= & \text { Net Interest Margin } \\
\mathrm{FiSi}= & \text { Firm Size } \\
\mathrm{OS}_{1}= & \text { Dummy of Ownership Status, } 1 \text { for } \\
& \text { private and } 0 \text { for government } \\
\mathrm{OS}_{2}= & \text { Dummy of Ownership Status, } 1 \text { for } \\
& \text { domestic ownership and } 0 \text { for } \\
& \text { foreign ownership }
\end{aligned}
$$

\section{Hypothesis Development}

Capital structure consists of 3 ratios, namely Capital Adequacy Ratio, Loan Fund Ratio and Leverage Ratio or Debt to Equity
Ratio. Banks are financial institutions that must have a vertical ratio, namely efficient debt to equity. If the Debt to equity is too small, then the bank will be inefficient in using its equity.

Meanwhile, the Loan to Fund Ratio also shows how a bank's treasury manages the use of public funds or deposits for distribution. If the Loan to deposit ratio is too small, the bank will experience a negative spread, on the other hand, if the Loan to deposit ratio reaches more than $100 \%$, then the bank will experience liquidity problems, where the funds channeled are greater than the deposits they have.

Capital adequacy ratio is a ratio that must be followed by all banks. The regulator sets a minimum CAR of $12 \%$. If it is below, the Bank is obliged to take a policy by increasing capital. The CAR ratio of $12 \%$ shows that the total capital after deducting the provision for credit risk is then compared to the total portfolio of financing provided. These ratios are very important for a bank, so the research has the following hypothesis

$\mathrm{H}_{1}$ : Capital structure have any influence on banks' return on asset

$\mathrm{H}_{2}$ : Capital structure have any influence on banks' return on equity

Credit risk is the main risk of a financial institution, including banking. The banking business is a risk business. Banks receive public funds and provide loans in the hope that they will be returned. This return will be a bank profit. Banking profits are obtained from the difference between the interest paid by the debtor and the interest that must be paid to the customer. If there are those who do not pay, the banking sector is at risk of loss. Because the interest on savings must still be paid, even though the loan funds have not been paid.

Credit risk consists of reserve requirements and non-performing loans. Reserve requirements will increase, if there is potential for bad credit to increase. Non-performing loans are the ratio of non-paying loans. The hypothesis is as follows: 
$\mathrm{H}_{3}$ : Credit risk have any influence on banks' return on asset

$\mathrm{H}_{4}$ : Credit risk have any influence on banks' return on equity

Net Interest Margin is the ratio of the difference between the percentage of loan interest given and the deposit interest received. The greater the ratio, the greater the banking profit, the smaller the ratio, the smaller the profit. The ratio has an important influence on profitability, so the hypothesis is:

$\mathrm{H}_{5}$ : Profit ratio have any influence on banks' return on asset

$\mathrm{H}_{6}$ : Profit ratio have any influence on banks' return on equity

The balance sheet of a bank consists of the amount of financing distributed. The greater the distribution of funds, the greater the size of the company. Banking is known as the term too big too fall. Large banks have large assets so that they have big profits. Small bank, has small assets, small profit. Thus, the firm size ratio will have an influence on profitability. The hypothesis is as follows:

$\mathrm{H}_{7}$ : Firm size have any influence on banks' return on asset

$\mathrm{H}_{8}$ : Firm size have any influence on banks' return on equity

The banking industry has grown very rapidly, especially for developing countries. Banking liberalization for foreign investors has been opened since the Asian crisis in 1998. However, the largest banks in each country are still owned by local banks. Foreign banks control the banking ownership of Asian countries. Foreign banks have brought better management to Asian countries. So this research uses the following hypothesis:

$\mathrm{H}_{9}$ : Ownership status have any influence on banks' return on asset

$\mathrm{H}_{10}$ : Ownership status have any influence on banks' return on equity

This study uses two profitability ratios. The profitability ratio consists of the return on equity ratio and the return on assets ratio. So that the total hypothesis becomes 10 hypotheses (table 2).

Table 2

Research Hypothesis

\begin{tabular}{clc}
\hline Hypothesis & Determinants & Expected Relationship to Profitability \\
\hline $\mathrm{H}_{1}$ & Capital Structure & Positive \\
$\mathrm{H}_{2}$ & Credit Risk & Negative \\
$\mathrm{H}_{3}$ & Profit & Positive \\
$\mathrm{H}_{4}$ & Firm Size & Positive \\
$\mathrm{H}_{5}$ & Ownership Status & Positive \\
\hline
\end{tabular}

Source: Research Results

Table 3

Research Variable

\begin{tabular}{ll}
\hline \hline \multicolumn{1}{c}{ Variables } & \multicolumn{1}{c}{ Measurements } \\
\hline Capital Structure & Capital Adequacy Ratio, Loan Fund, Leverage \\
Credit Risk & Non-Performing Loans - Gross, Reserve Requirement Ratio \\
Profit & Net Interest Margin \\
Firm Size & FiS = ln (Total Assets) \\
Ownership Status & Private and Government Ownership \\
& Foreign and Local Ownership \\
\hline
\end{tabular}




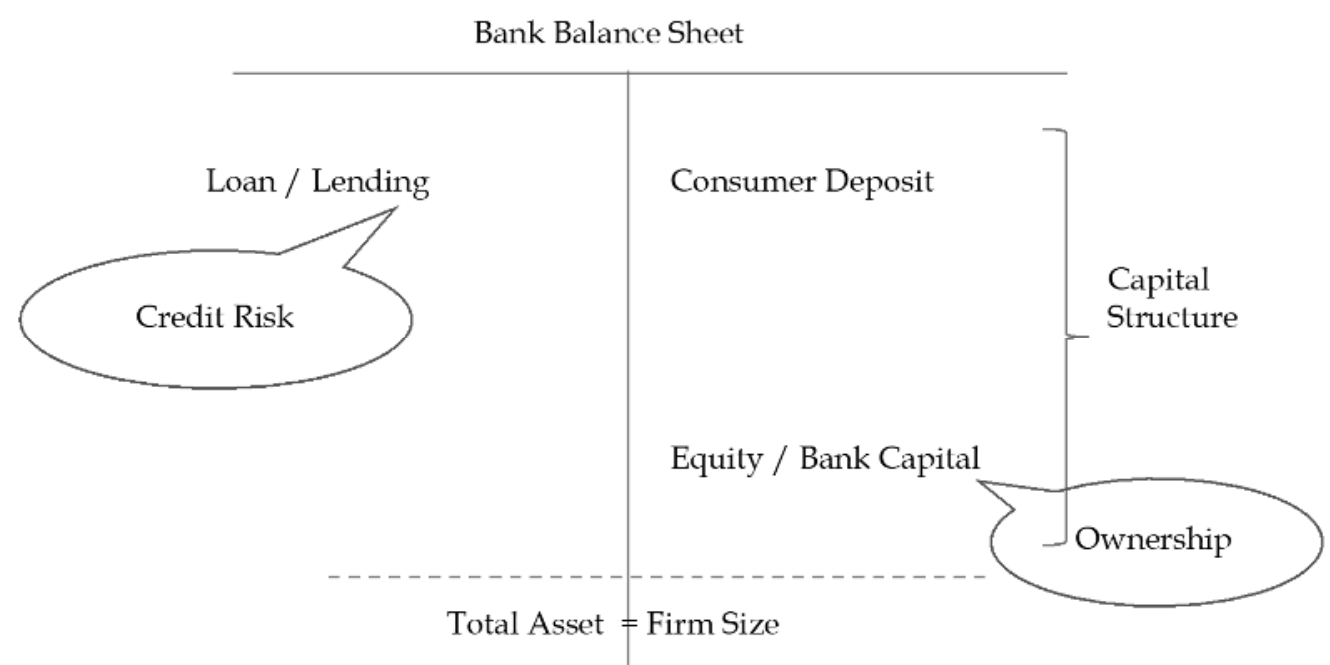

Figure 2

Source: Research Results

\section{Bank Balance Sheet}

Bank Income Statement

\begin{tabular}{ll} 
Revenue / Interest Income & $\mathrm{xx}$ \\
Cost of Fund / Interest Expense & $\mathrm{xx}$ \\
\hline Net Interest Margin (NIM) & $\mathrm{xx}$ \\
Provision For Doubtful Account & $\mathrm{xx}$ \\
Expenses & $\mathrm{xx}$ \\
Tax & $\mathrm{xx}$ \\
\hline Net Income & $\mathrm{xx}$
\end{tabular}

Figure 3

Source: Research Results

\section{Bank Income Statement}

The premise is that capital structure, profit, and company size will have a beneficial influence on bank profitability performance, based on past research. Bank profitability will suffer as a result of credit risk. The ownership position of a bank will also have a favorable impact on its profitability. The following are the variables and measurements in Table 3.

The position of each ratio in the banking financial statements is depicted in Figure 2 and Figure 3.
Secondary statistics were acquired from a variety of approved publications by the organizations for this study. The data are panel data from 2016 to 2018, with crosssection and time-series data. The banks that issued their permitted financial reports throughout the research period make up the sample. The banks are classified as Books 3 and 4 . There were 19 banks in the sample. The Otoritas Jasa Keuangan/Financial Service Authority regulates all banks (FSA). The variables' formulation is provided in Table 3. 


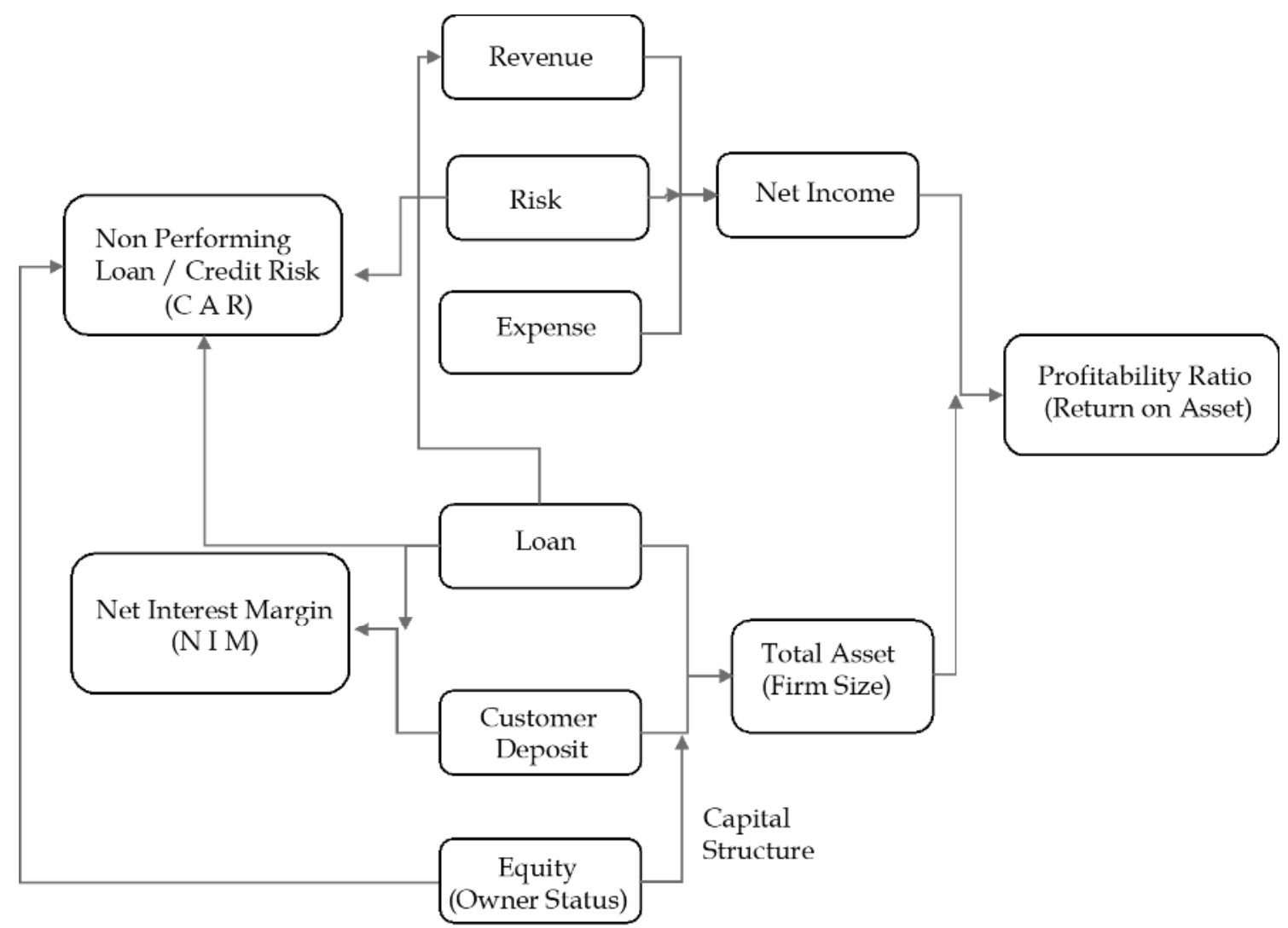

Figure 4

Source: Research Results

\section{Research Framework}

The relationship between items in the financial statements and research variables is described in Figure 4 in building return $n$ asset. Return on assets is total net income divided by total assets. Total assets consist of customer deposits with equity or loans disbursed to consumers.

Net income is the result of revenue minus costs and risks. Revenue is generated from the loan channeled. Fees represent fees for obtaining deposits and distributing funds. Credit risk is the risk of bad credit.

The relationship between items in the financial statements and research variables is described in Figure 5 in building return on equity. Return on equity is total net income divided by total equity. Total equity consists of the paid capital of the firm, retained earning of profit and other equity items.

Net income is the result of revenue minus costs and risks. Revenue is generated from the loan channeled. Fees represent fees for obtaining deposits and distributing funds. Credit risk is the risk of bad credit.

The source income of banking comes from interest income minus expenses. Expenses represent operational expenses and credit or risk expenses. Fast growing banks have a tradeoff between risk and growth. Rapid growth carries an increase of risk, if the bank will not be able to balance with precautionary principles. 


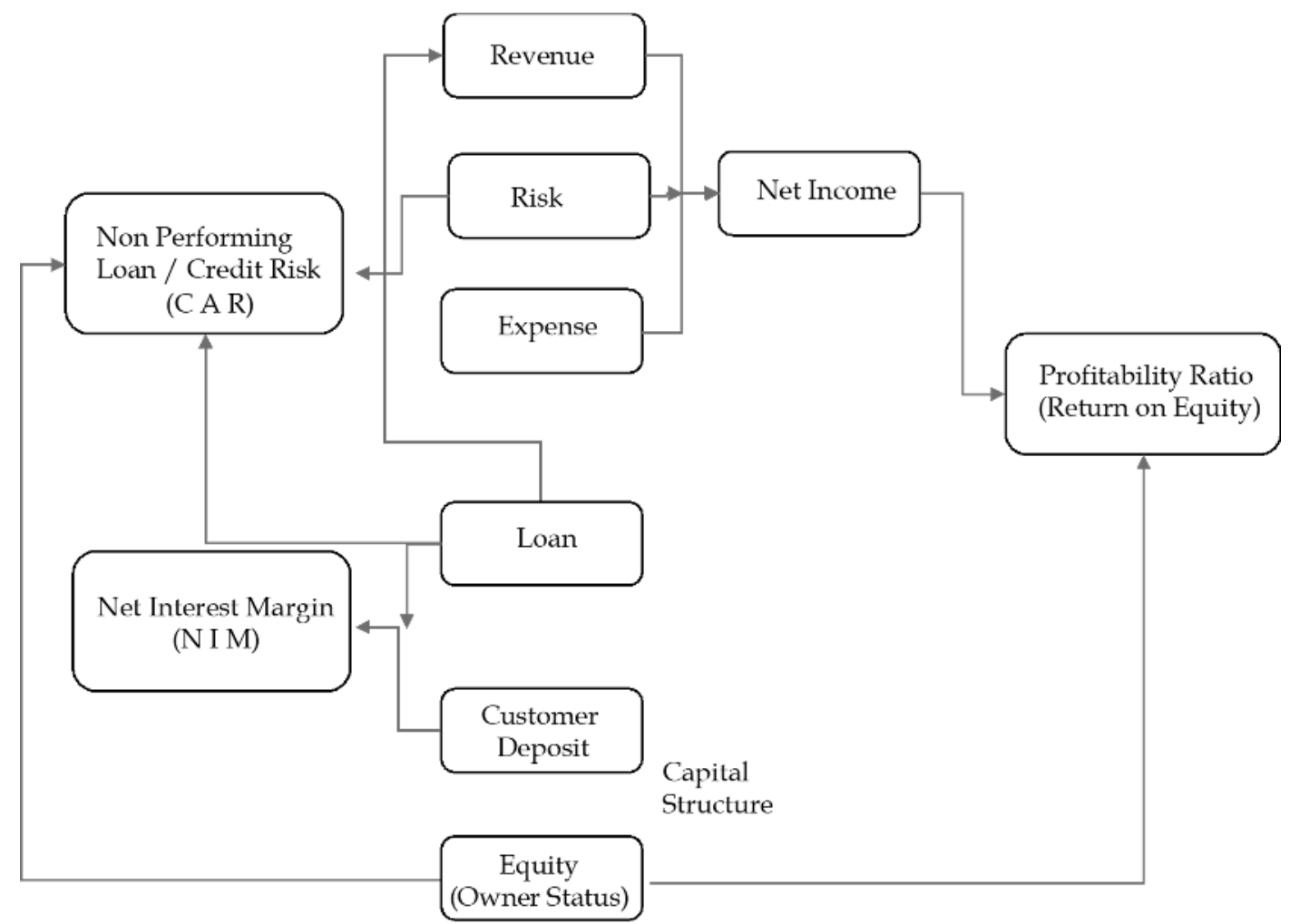

Figure 5

Source: Research Results

Research Framework

The biggest cost of banking is the cost of consumer deposits or funding costs. The difference between interest income and funding interest is an interest margin. Interest income less interest funding costs less the risk of allowance for uncollectible loans become the contribution value or gross profit in the manufacturing company. This gross profit after deducting operating expenses becomes income before tax.
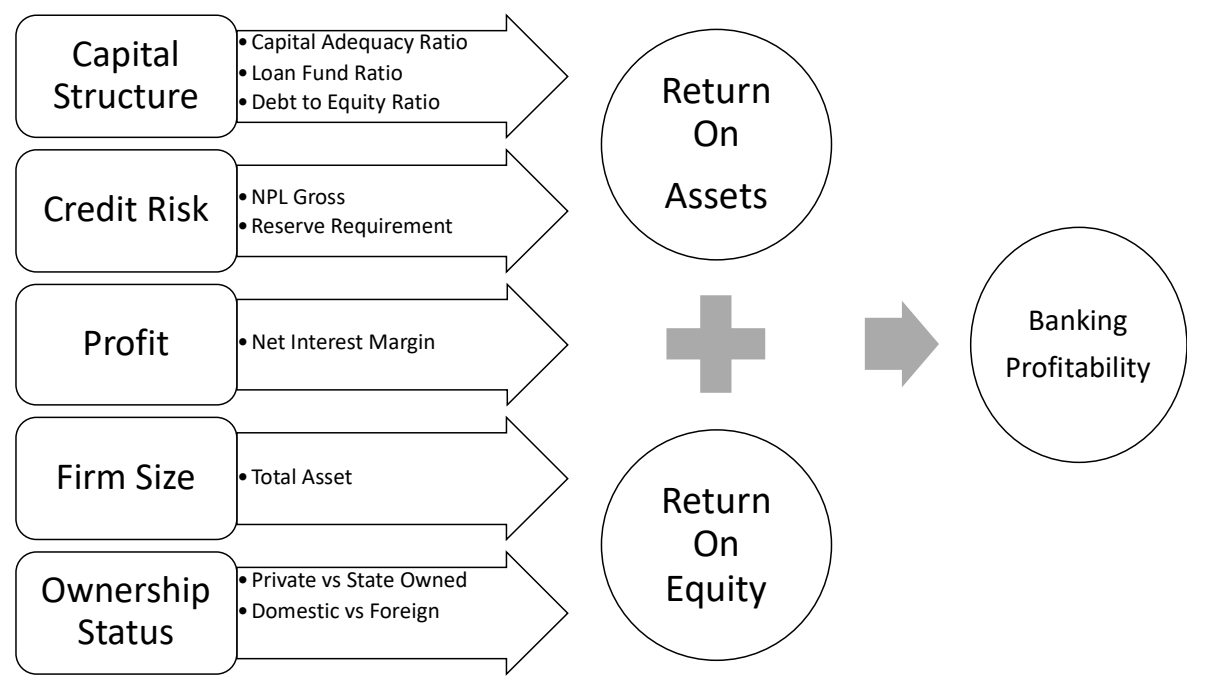

Figure 6

Source: Research Results

Research Framework 
This study uses 5 research variables, namely capital structure, credit risk, profitability, firm size and ownership stauts. Each research variable is described in 9 measures. Each variable is measured by 1 measure or more than 1 measurements.

Each variable is examined for its influence on the profitability ratio. The profitability ratio uses the return on assets ratio and the return on equity ratio. The return on asset ratio reflects how the performance of assets in generating profits. Banking is an industry that has assets in the form of funding and deposits. Banking assets reflect the ability to generate profitability. The return on equity ratio reflects the ability of capital to generate profits. The return on equity ratio reflects the return to shareholders. This ratio also reflects the company's ability to provide returns to investors. This explanation is depicted in Figure 6.

\section{ANALYSIS AND DISCUSSION}

Based on Table 4, The ROA has the lowest -4.89 percent ratio and the highest 4.34 percent ratio. The ROA was 1.93 percent on average. Meanwhile, the average Return On Investment (ROI) is 11.95 percent. The best Return On Investment (ROI) was 28.04 percent, while the lowest was -38.33 percent.

In terms of CAR, the bank achieved an average of 19.72 percent, which was more than the regulation threshold of 12 percent. The lowest percentage was 13.34 percent, while the highest percentage was $30.00 \%$. Bank Indonesia or Financial Services Authority requires Bank Capital Adequacy Ratio to reach a minimum of $8 \%$. Banks are required to provide a plan for improvement of CAR if it has reached $12 \%$. The bank must provide a CAR improvement plan through additional capital from shareholders or subordinated loans.

The loan to fund ratio was 85.51 percent on average in the sample analyzed. The lowest percentage was 71.35 percent, while the highest percentage was 95.54 percent. The Loan to Fund Ratio demonstrated that the bank's capacity to lend outweighed its capacity to fund. Loan to funding is a crucial ratio. If the loan to funding exceeds $100 \%$, the loan amount exceeds the customer's deposit funds. This can happen, if the bank finances part of the loan with its own capital.

On average, banks attained a debt-toequity ratio of $6.84 \mathrm{x}$ their equity. The greatest debt-to-equity ratio is $11 x$, while the lowest is $2.79 x$.

The highest non-performing loans was $8.83 \%$ of the total lending amount. The lowest was $0.73 \%$, and on average, the nonperforming loans is $2.83 \%$. The non-performing loans should not be more than 5\% based on regulations. Non-performing loans reaching $8.83 \%$ are a condition in which banks need to determine remedial actions.

Table 4

Descriptive Statistics

\begin{tabular}{lcccc}
\hline \hline \multicolumn{1}{c}{ Equation } & N & Minimum & Maximum & Mean \\
\hline ROA & 57 & -4.89 & 4.34 & 1.93 \\
ROE & 57 & -38.33 & 28.04 & 11.95 \\
CAR & 57 & 13.34 & 30.00 & 19.72 \\
Loan To Fund & 57 & 71.35 & 95.54 & 85.51 \\
Debt To Equity & 57 & 279.20 & $1,133.20$ & 684.72 \\
Non-Performing Loan & 57 & 0.73 & 8.83 & 2.83 \\
Reserve Requirement & 57 & 5.04 & 99.05 & 8.33 \\
Net Interest Margin & 57 & 3.76 & 10.10 & 5.76 \\
Firm Size & 57 & 17.75 & 20.84 & 19.00 \\
\hline
\end{tabular}

Source: Research Results 
Table 5

Research Results on ROA and ROE

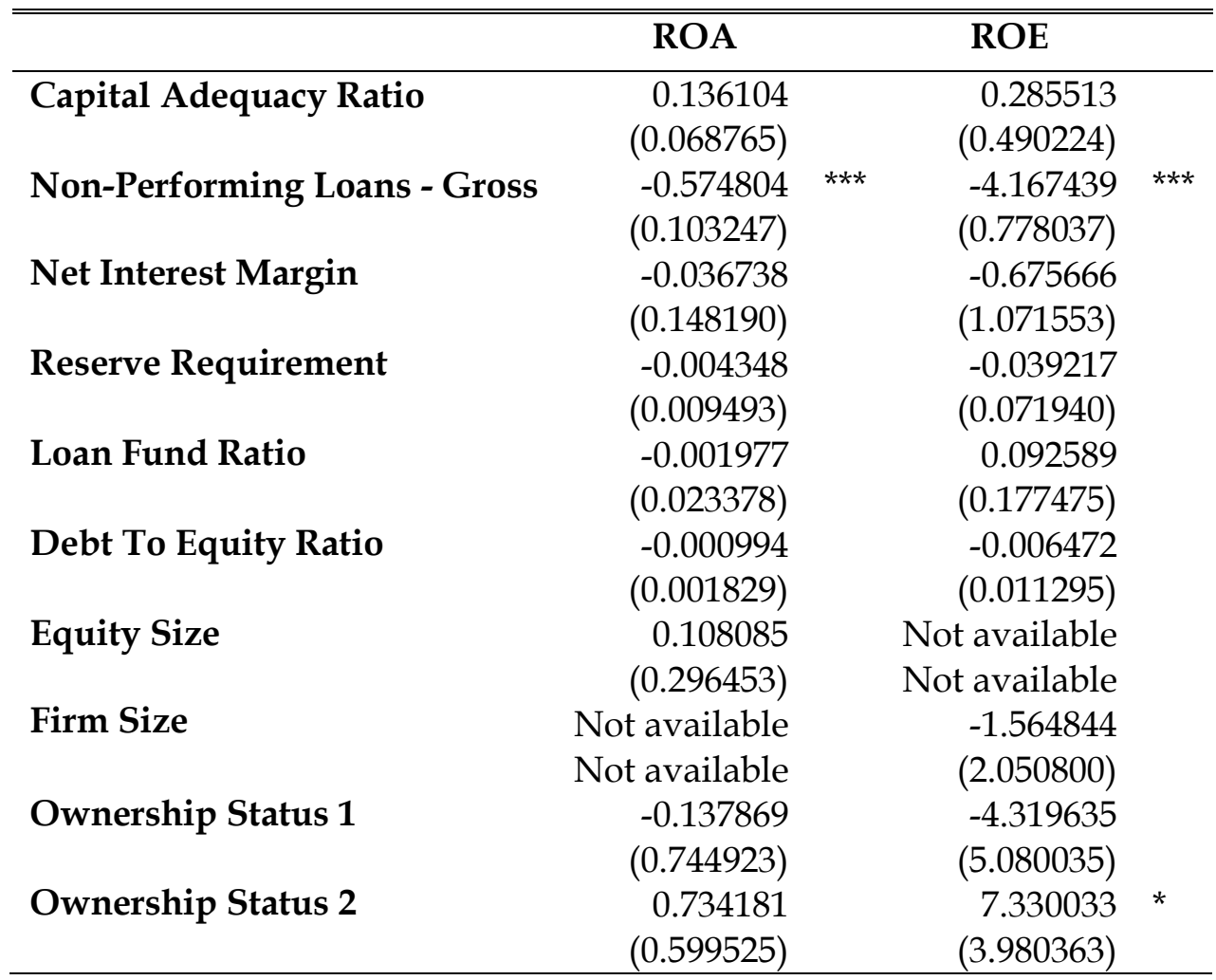

Source: Research Results

Note : *) Significant at $\alpha=10 \%$

**) Significant at $a=5 \%$

$* * *)$ Significant at $\alpha=1 \%$

The reserve requirement, on average, reached $8.33 \%$. The lowest reserve was $5.04 \%$, and the highest reserve was $99.05 \%$. The reserve of $99.05 \%$ is the worst reserve ratio. The average net interest margin for the banks was 5.76 percent. The best net interest margin was 3.76 percent, while the worst was 10.10 percent. If the interest margin $10.10 \%$ and the reserve ratio is $5.04 \%$, the net margin is $5.06 \%$. If the highest margin and the lowest rate is in the same bank. However, if the lowest interest margin is $3.76 \%$ and the reserve requirement is $99.05 \%$, the performance of the bank will be minus $95.29 \%$.

The Random Effect Model (REM) was found to be the best suited model to explain the research results based on the findings of the Hausman and LM tests. Table 5 displays the REM results.
The capital adequacy ratio, loan fund ratio, and debt to equity ratio had no significant influence on ROE and ROA. The findings of this study agree with those of Zaid et al., (2014) and Lipunga (2014), who concluded that liquidity had no impact on profitability. Capital adequacy ratio is the ratio of capital adequacy to potential credit risk. Potential credit risk is a provision for doubtful credit. Loan to fund ratio is a ratio that shows the ratio of lending to consumer deposits. This ratio shows banking liquidity.

Debt to equity ratio shows the capital structure of banking. This capital structure for banking can reach up to 10x. Bank capital structure must be an efficient structure. Banks that have an inefficient capital structure will generate a negative margin. So that capital structure is an essential ratio for 
banks. This ratio is known as the Capital Adequacy Ratio (CAR).

Non-performing loans acquired a statistical value of -0.574804 and is significant at $\mathrm{a}=1 \%$ on ROA and a statistical value of 4.167439 and is significant at $\mathrm{a}=1 \%$ on $\mathrm{ROE}$ using the random effect model. Table 5 summarizes the most important findings.

As a result, non-performing loans have a detrimental impact on a company's profitability. It demonstrated that banks, as financial entities, have a key responsibility for risk management. The findings back up Tariq's (2014), Capraru and Ihnatov's (2015), Petria et al., (2015), Mwangi and Murigu's (2015), and Chou and Buchdadi's (2015) studies (2016).

Credit risk is the most significant implication risk for bank profitability. This is could be seen in the 2008 global crisis. Large banks are experiencing financial difficulties and the government is buying out by injectting funds, and diverting problem assets from the banks to a special purpose vehicle company.

The net interest margin has no major influence on ROE and ROA. It has been proven that a greater yield entails a larger risk. A greater yield may not boost a bank's profitability. Profit margin is recorded at revenue or interest income at the income statement. The principle of high-risk highreturn reflects that the greater profit margin results in incre-ased risk. So that the net-off between interest and risk, profit does not increase.

Banks can get a large net interest margin but the consumer segment is at risk. So that the net interest interest margin is reduced by the risks that arise, then the profitability will not increase. Banking income can be increased by increasing fee-based income. Fee based income has no risk.

There were no significant effects of bank size on ROE and ROA. The findings revealed that the size of an asset has no bearing on its profitability. Banking, on the other hand, was notorious for being "too big to fail."
Bank size has no influence on profitability is a result that needs to be examined more deeply. The research focuses on bank category 3 and 4 , where these banks have total assets and total equity that fall into the same category, thus, this study finds that firm size or bank size has no effect on profitability.

Because the results of this study are different from the results of many previous researchers such as Lipunga (2014), Zaid et al., (2014), Tui et al., (2017), Petria et al., (2015), Mwangi and Murigu (2015). The addition of a sample with a diversified sample size will illustrate more precise conditions.

Total bank assets will continuously be measured through the CAR ratio. The higher the assets, the higher the equity, and is constructed on capital structure ratio. Total assets and capital structure do not have a significant effect on profitability. The data of the research is bank book 3 and 4 , where as the bank have an equal position in terms of assets.

Based on Table 6, there were no substantial effects of private or publicly held shareholders on banking profitability. There is no difference between state-owned and private banks, because government bank management has acted professionally. The financial industry is a very tight industry and there are very few differences between the government and the private sector. So that the status of private and government ownership has no difference.

The findings revealed that the backing of local shareholders had an influence on banking profitability. However, it had a detrimenttal influence. The research results support the study by Ozili and Uadiale (2017). The test results also show that banking must be run in a professional manner, intervention by shareholders will have a negative impact on the bank. This supports the need to implement good corporate governance in banking. This will support regulators to implement good corporate governance in financial institutions. 
Table 6

Research Summary

\begin{tabular}{lcc}
\hline \multicolumn{1}{c}{ Determinants } & Relationship to ROA & Relationship to ROE \\
\hline Capital structure & - & - \\
Credit Risk & Significant (Negative) & Significant (Negative) \\
Profit & - & - \\
Firm Size & - & - \\
Ownership Status & - & Significant (Negative) \\
\hline
\end{tabular}

Source: Research Results

Based on Bank Indonesia regulations, all shareholders have the same obligations in dealing with problem banks, such as capital adequacy ratio. The category of shareholder obligations is based on the status of shareholders such as banking institutions, nonbanking institutions, and individuals. The origin status of institutions and individuals does not form the basis of measurement, so the results of this study did not find significant differences.

Based on the research results, company management should focus on credit risk to be able to raise the ROA and ROE of the bank. Lending risk is the most critical factor that will impact the capital adequacy ratio, non-performing loans, and reserve requirement. Hence, the results also showed that the domestic Indonesia shareholders contribute more than foreigners to the profitability of the bank.

\section{CONCLUSIONS AND SUGGESTIONS Conclusions}

The key element that determines the banking ROA and ROE is credit risk. As a result, the portfolio's non-performing loans took essential point. Increased non-performing loans will need increased reserve requirements. Reserve requirements that are higher will have an impact on profitability and capital adequacy ratio. Managing the credit procedure is critical.

Local investors were more supportive of banks profitability than international investors. It said that local knowledge and familyarity are benefits in the banking rivalry. Domestic shareholders have a negative influ- ence. Banking must run independently. Good corporate governance must be implemented. If not, shareholder support will result in negative.

Capital structure, profit margin, firm size, and ownership status do not show significant results on profitability. This illustrates that the firm size and capital structure has a standard measurement. The profit margins adhere to the principle of high-risk highreturn, so it has no implications on profitability after net-off the margin with risk. Whereas ownership status is not based on domestic or foreign status but based on legal entity status.

\section{Suggestions}

According to the research results, banks should concentrate on credit, funding, and lending policies. Indonesian shareholders, on the other hand, are more supportive of banks than international owners. The findings of this research also show that regulators must concentrate on assessing bank risk.

Banking management must be able to handle the risks that result from providing credit. The banking business is a risk business. If risks are handled properly, then profitability, banks will achieve good results.

Further research can be developed in other industries such as service and manufacturing companies. Research for the same industry can be separated according to the gross domestic product per capita category and the addition of other macro variables to the research.

Other research can be developed based on the research period. The research period 
is important because different periods will produce different performances. The macroeconomic situation has a very significant impact on financial performance. Banking risk and banking income are strongly influenced by interest. High interest rates, business activity does not work, which creates banking risks. The research results support the decline in banking performance as a result of increased risk. The conditions of the Covid-19 pandemic have shown an increase in business risk, especially in banking-related industries. Many companies have gone bankrupt.

\section{Limitations}

This research only focuses on bank book 3 and book 4 . Bank under book 3 and book 4 are banks that have sufficient capital. Bank book 3 and book 4 have significant market share in the total banking industry. However, the banks in book 1 and book 2 have more numbers than book bank 3 and book bank 4 .

In addition, this study has limitations that only focus on micro banking variables. Research also needs to focus on macro variables. The Macro variables could be the exchange rate, inflation rate and interest rate. Micro variables are variables that can be controlled by management of banks. Macro variables are variables that cannot be controlled by banks. This research also has limitations on a short cycle macroeconomic condition. Research can be developed over a longer period of time and includes several economic cycles.

\section{REFERENCES}

Abdillah, R., N. M. Hosen, and S. Muhari. 2016. The Determinants Factors of Islamic Bank's Profitability and Liquidity in Indonesia. Knowledge Horizons Economics 8(2): 140-147.

Abel, S. and P. Le Roux. 2016. Determinants of Banking Sector Profitability in Zimbabwe. International Journal of Economics and Financial Issues 6(3): 845-854.
Adelopo, I., R. Lloydking, and V. Tauringana. 2018. Determinants of Bank Profitability Before, During and After the Financial Crisis. International Journal of Managerial Finance 14(4): 378-398.

Ahmad, G. N. 2015. Determinan Profitabilitas Bank: Studi Kasus Pada Bank Pembangunan Daerah. Jurnal Keuangan dan Perbankan 19(3): 431-438.

Alshatti, A. S. 2016. Determinants of Banks' Profitability - The case of Jordan. Investment Management and Financial Innovations 13(1): 84-91.

Batten, J. A. and X. V. Vo. 2017. Determinants of Bank Profitability Evidence from Vietnam. Emerging Markets Finance and Trade 55: 1417-1428.

Béjaoui, R. and H. Bouzgarrou. 2014. Determinants of Tunisian Bank. The International Journal of Business and Finance Research 8(4): 121-131.

Boateng, K. 2018. Determinants of Bank Profitability: A Comparative Study of Indian and Ghanaian Banks. Journal of Emerging Technologies and Innovative Research 5(5): 643-654.

Capraru, B. and I. Ihnatov. 2014. Bank's Profitability in Selected Central and Eastern European Countries. 21 ${ }^{\text {st }}$ International Economic Conference 2014 Sibiu, Romania. Procedia Economics and Finance 16(2014): 587-591.

Capraru, B. and I. Ihnatov. 2015. Determinants of Bank's Profitability in EU15. De Gruyter Open, Scientific Annals of the "Alexandru Ioan Cuza" University of Iasi, Economic Sciences 62(1): 93-101.

Chou, T. and A. D. Buchdadi. 2016. Bank Performance and Its Underlying Factors: A Study of Rural Banks in Indonesia. Accounting and Finance Research 5(3): 5563.

Dietrich, A. and G. Wanzenried. 2014. The Determinants of Commercial Banking Profitability in Low, Middle, and HighIncome Countries. The Quarterly Review of Economics and Finance 54(2014): 337354. 
Ebenezer, O. O., W. A. W. B. Omar, and S. Kamil. 2017. Bank Specific and Macroeconomic Determinants of Commercial Bank Profitability: Empirical Evidence from Nigeria. International Journal of Finance E Banking Studies 6(1): 25-38.

Ercegovac, R., I. Klinac, and I. Zdrilić. 2020. Bank Specific Determinants of EU Banks Profitability after 2007 Financial Crisis. Management (Croatia) 25(1): 89-102.

Haryanto, S. 2016. Profitability Identification of National Banking through Credit, Capital, Capital Structure Efficiency and Risk Level. Jurnal Dinamika Manajemen 7(1): 11-21.

Hasanov, F., N. Bayramli, and N. AlMusehel. 2018. Bank-Specific and Macroeconomic Determinants of Bank Profitability: Evidence from an Oil-Dependent Economy. International Journal of Financial Studies 6(3): 78.

Islam, M. S. and S. Nishiyama. 2016a. The Determinants of Bank Profitability: Dynamic Panel Evidence from South Asian Countries. Journal of Applied Finance $\mathcal{E}$ Banking 6(3): 77-97.

Islam, M. S. and S. I. Nishiyama. 2016b. The Determinants of Bank Net Interest Margins: a Panel Evidence from South Asian Countries. Research in International Business and Finance 37(3): 501-514.

Islam, M. A., M. N. I. S. Sarker, M. Rahman, A. Sultana, and A. S. Prodhan. 2017. Analysis of Determinants of Profitability of Commercial Banks in Botswana. International Journal of Academic Research in Accounting, Finance and Management Sciences 7(2): 1-11.

Javid, M. E. 2016. Bank Specific and Macroeconomic Determinants of Bank Profitability. Journal of Management Info 3(2): 14-18.

Lipunga, A. M. 2014. Determinants of Profitability of Listed Commercial Banks in Developing Countries: Evidence from Malawi. Research Journal of Finance and Accounting 5(6): 41-49.

Majumder, M. T. H. and M. J. Uddin. 2017. The Determinants of Profitability of
Nationalised Banks in Bangladesh. International Journal of Economics and Business Research 13(4): 335-348.

Marnilin, F. and J. M. V. M. Darmansyah. 2015. Analisis Determinan Terhadap Persistensi Laba Pada Perusahaan Jasa di BEI. Media Riset Akuntansi, Auditing, $\mathcal{E}$ Informasi 15(1): 89-102.

Maryadi, S. and T. A. Basuki. 2014. Determinan Kinerja Keuangan Bank Perkreditan Rakyat Konvensional. Jurnal Ekonomi dan Studi Pembangunan 15(1): 55-63.

Mwangi, M. and J. W. Murigu. 2015. The Determinants of Financial Performance in General Insurance Companies in Kenya. European Scientific Journal 11(1).

OJK (Otoritas Jasa Keuangan). 2021. Banking Industry Statistic. https://www.ojk.go.id/ id/kanal/perbankan/data-dan-statistik/ statistik-perbankan-indonesia/default.aspx.

Ozgur, O. and M. S. Gorus. 2016. Determinants of Deposit Bank Profitability: Evidence from Turkey. Journal of Applied Economics and Business Research (JAEBR) 6(3): 218-231.

Ozili, P. K. and O. Uadiale. 2017. Ownership Concentration and Bank Profitability Future. Business Journal 3: 159-171.

Petria, N., B. Capraru, and I. Ihnatov. 2015. Determinants of Banks' Profitability: Evidence from EU27 Banking System. $7^{\text {th }}$ International Conference on Globalization and Higher Education in Economics and Business Administration, GEBA 2013. Procedia Economics and Finance 20: 518524.

Rahman, H. U., M. W. Yousaf, and N. Tabassum. 2020. Bank-Specific and Macroeconomic Determinants of Profitability: a Revisit of Pakistani Banking Sector under Dynamic Panel Data Approach. International Journal of Financial Studies 8(3): 1-19.

Rani, D. M. S. and L. N. Zergaw. 2017. Bank Specific, Industry Specific and Macroeconomic Determinants of Bank Profitability in Ethiopia. International Journal of Advanced Research in Management and Social Sciences 6(3): 74-96. 
Rekik, M. and M. Kalai. 2018. Determinants of Banks' Profitability and Efficiency: Empirical Evidence from a Sample of Banking Systems. Journal of Banking and Financial Economics 1(9): 5-23.

Sahyouni, A. and M. Wang. 2018. The Determinants of Bank Profitability: Does Liquidity Creation Matter? SSRN Electronic Journal 2(2): 61-85.

Samad, A. 2015. Determinants Bank Profitability: Empirical Evidence from Bangladesh Commercial Banks. International Journal of Financial Research 6(3): 173-179.

Saona, P. 2016. Intra- and Extra-Bank Determinants of Latin American Banks' Profitability. International Review of Economics and Finance 45: 197-214.

Tan, Y. 2016. The Impacts of Risk and Competition on Bank Profitability in China. Journal of International Financial Markets 40(2016): 85-110.

Tariq, W. 2014. Determinants of Commercial Banks Profitability: Empirical Evidence from Pakistan. International Journal of Accounting and Financial Reporting 4(2): 1-22.

Tui, S., M. Nurnajamuddin, M. Sufri, and A. Nirwana. 2017. Determinants of Profitability and Firm Value: Evidence from Indonesian Banks. IRA-International Journal of Management \& Social Sciences 7(1): 84-95.
Utami, T. and I. W. Kusuma. 2017. Determinan Kualitas Laba pada Isu Pengadopsian International Financial Reporting Standard: Data dari Asia. Jurnal Akuntansi and Investasi 18(1): 1-12.

Yao, H., M. Haris, and G. Tariq. 2018. Profitability Determinants of Financial Institutions: Evidence from Banks in Pakistan. International Journal of Financial Studies 6(2): 53.

Yüksel, S., S. Mukhtarov, E. Mammadov, and M. Özsarı. 2018. Determinants of Profitability in the Banking Sector: an Analysis of Post-Soviet Countries. Economies 6(41): 1-15.

Zaid, N. A. M., W. M. F. W. Ibrahim, and N. S. Zulqernain. 2014. The Determinants of Profitability: Evidence from Malaysian Construction Companies. Proceedings of 5th Asia-Pacific Business Research Conference, Hotel Istana, Kuala Lumpur, Malaysia.

Zainuddin, P., Z. Wancik, S. A. Rahman, S. HartatI, and F. A. Rahman. 2017. Determinant of Financial Performance on Indonesia Bank through Return on Assets. International Journal of Applied Business and Economic Research 15(20): 243-251.

Zampara, K., M. Giannopoulos, and D. N. Koufopoulos. 2017. Macroeconomic and Industry-Specific Determinants of Greek Bank Profitability. International Journal of Business and Economics Sciences Applied Research 10(1): 13-22. 